\title{
Growth of lactic acid bacteria in milk phospholipids enhances their adhesion to Caco-2 cells
}

\author{
Diana Rocha-Mendoza, Erica Kosmerl, (-) Gonzalo Miyagusuku-Cruzado, M. Mónica Giusti, \\ Rafael Jiménez-Flores, (iD and Israel García-Cano* (D) \\ Department of Food Science and Technology, Parker Food Science and Technology Building, The Ohio State University, Columbus 43210
}

\begin{abstract}
The mechanisms of bacterial adhesion to human cells involve several complex reactions and activation of genes and proteins. It has been reported that the food components in dairy matrices, such as sugar or salt, can decrease bacterial adhesion to Caco- 2 cells. However, it has not been evaluated whether the bacteria grown in media supplemented with milk phospholipids (MPL) can increase or decrease the adhesion of these cells. The objective of this work was to evaluate the effects of MPL on the kinetic growth of lactic acid bacteria (LAB) and their functional characteristics as probiotics, expression of surface protein genes, and adherence to Caco-2 cells. Seven LAB strains isolated from various dairy products were characterized. Five of the tested LAB strains were able to grow in a chemically defined medium supplemented with MPL. Lactobacillus reuteri OSU-PECh-48 showed the highest growth rate and the greatest optical density. All of the strains tested showed tolerance to acidic conditions at $\mathrm{pH} 3.0$ and to bile salts at 0.5 and $1 \%$ concentrations. Auto-aggregation and cell surface hydrophobicity ability were evaluated, with nonsignificant differences between the strains grown in MPL and without MPL. Gene expression of 6 surface proteins was evaluated in the presence or absence of MPL. Pediococcus acidilactici OSU-PECh-L and OSUPECh-48 were the strains with highest relative expression of 5 of the 6 genes evaluated. Lactobacillus paracasei OSU-PECh-BA was the strain with the lowest level of expression of surface protein genes. Most of the bacteria tested had increased adhesion to Caco-2 cells after growth in MPL. The bacteria with the highest degrees of adhesion observed were Lactobacillus paracasei OSU-PECh-3B, Pediococcus acidilactici OSU-PECh-L, and Lactobacillus reuteri OSU-PECh-48. The genes $C n b$ and EF-Tu increased in expression in the presence of MPL in most of the LAB tested. The results
\end{abstract}

Received January 28, 2020.

Accepted May 3, 2020.

*Corresponding author: garciacano.1@osu.edu obtained in this work demonstrate the high potential of these LAB strains for use as starters or beneficial cultures in fermentation of not only dairy products but also other food fermentation processes, with promising ability to increase residence time in the gut, modify the microbiome, and improve human health.

Key words: lactic acid bacteria, milk phospholipids, adhesion to Caco-2 cells

\section{INTRODUCTION}

Milk phospholipids (MPL) are amphiphilic lipids that actively participate in the emulsification of fat in milk. These MPL, together with proteins, are the main constituents of the milk fat globule membrane (MFGM). The most prominent MPL include glycerophospholipids, namely phosphatidylcholine (PC), phosphatidylethanolamine (PE), phosphatidylinositol (PI), and phosphatidylserine (PS), and sphingolipids, with the most abundant being sphingomyelin (SM; Contarini and Povolo, 2013). Phospholipids (PL) have beneficial health effects on numerous cell functions, including growth and development, absorption processes, memory, stress responses, myelination of the central nervous system, regulation of inflammatory responses, inhibition of cholesterol absorption, and some chemopreventive and chemotherapeutic activities in some types of cancer (Spitsberg, 2005; Hartmann et al., 2009; Schubert et al., 2011).

Lactobacillus and Bifidobacterium, among others, are the most used probiotics in food industry (Ranadheera et al., 2010). These probiotics have been reported to have anti-diabetic effects. Type 2 diabetes has been correlated with reduced probiotic and increased gramnegative Bacteroidetes, which directly influence plasma glucose concentration (Barrett et al., 2012). The strains Lactobacillus fermentum NCIMB-5221, Lactobacillus acidophilus ATCC 314, and Lactobacillus rhamnosus ATCC 51303 have proven highly potent in suppressing colorectal cancer cells, due to ferulic acid production (Lee at al., 2019) and anti-inflammatory effects (Currò et al., 2017). Diets enriched with lactic acid bacteria 
(LAB) and MPL reduce the inflammatory response to lipopolysaccharides in mice, which is correlated with decreased gut permeability (Snow et al., 2011). Dairy products are a major source of sphingolipids, which are abundant in the membranes of the absorptive intestinal epithelium. The products resulting from their digestion (ceramides and sphingosine) are considered potent bioactive compounds having important effects on the cell (Danielsen and Hansen, 2006). Nevertheless, intact sphingomyelin and ceramide are poorly absorbed, and their breakdown is a slow and incomplete process. The use of LAB in fermented dairy products, such as yogurt, has been shown to enhance absorption of dietary SM (Morifuji et al., 2017).

Lactic acid bacteria are present in a wide variety of fermented food products, and many are "generally recognized as safe" for applications as probiotics and as bioprotective cultures in dairy products. According to the definition from the Food and Agriculture Organization and the World Health Organization (FAO/WHO 2002), probiotics are "living microorganisms that, when administered in adequate amounts, confer a health benefit on the host." It is well recognized that supplementing fermented milk with probiotic LAB can enhance its nutritional value and therapeutic properties (Penna et al., 2015). Among the many characteristics desired and provided by LAB are the ability to adhere to the digestive mucosa, alter gut ecology, maintain the gut mucosal barrier, and modulate the immune response through interaction with the gut-associated immune system (Penna et al., 2015). Adhesion is considered an important characteristic for probiotic selection and is a prerequisite for bacterial prevalence, or at least significantly increases bacterial residence in the human gut. The objective of this study was to investigate 7 LAB strains that previously showed lipolytic activity (García-Cano et al., 2019) for their growth abilities in MPL and their effects on adherence to Caco-2 cells. The following $7 \mathrm{LAB}$ strains were tested: Pediococcus acidilactici OSU-PECh-L, Lactobacillus casei OSUPECh-C, P. acidilactici OSU-PECh-3A, Lactobacillus plantarum OSU-PECh-BB, Lactobacillus paracasei OSU-PECh-BA, L. paracasei OSU-PECh-3B, and Lactobacillus reuteri OSU-PECh-48, and their properties as probiotics were analyzed.

\section{MATERIALS AND METHODS}

\section{Strains, Growth Conditions, and Growth Kinetics}

The LAB used in this work were previously isolated and reported by García-Cano et al., (2019), with the exception of $L$. reuteri OSU-PECh-48 (accession number: SUB6712883). This strain was isolated and identi- fied from buttermilk (Dairy America, Fresno, CA). The $16 \mathrm{~S}$ rRNA sequences for each strain were deposited in GenBank (https://www.ncbi.nlm.nih.gov/genbank/ ) under the following accession numbers: P. acidilactici OSU-PECh-L MK543955; L. casei OSU-PECh-C MK543956; P. acidilactici OSU-PECh-3A MK543958; L. paracasei OSU-PECh-3B MK543959; L. paracasei OSU-PECh-BA MK543960; and L. plantarum OSUPECh-BB MK543961. To evaluate the ability of LAB to grow in MPL (Fonterra, Auckland, New Zealand), a chemically defined medium (CDM) was supplemented with different MPL concentrations.

Each isolated bacterium was stored at $-80^{\circ} \mathrm{C}$ in cryovials containing de Man, Rogosa, and Sharpe broth (MRS; Difco, Franklin Lakes, NJ) and glycerol $(80 / 20 \%)$. Each strain was reactivated by adding 20 $\mathrm{mL}$ to $5 \mathrm{~mL}$ of fresh MRS broth in culture tubes and incubating at $37^{\circ} \mathrm{C}$ for $12 \mathrm{~h}$. The overnight culture was collected by centrifugation at $8,000 \times g$ for 10 min at $4^{\circ} \mathrm{C}$ (Centrifuge 5804R, Eppendorf, Hamburg, Germany). The pellet was resuspended in sterile saline solution (SSS; $0.85 \% \mathrm{NaCl}, \mathrm{pH} 7.0$ ) until an optical density at $600 \mathrm{~nm}\left(\mathbf{O D}_{600 \mathrm{~nm}}\right)$ of 0.1 was reached, using a microplate reader (Multiskan GO, Thermo Fisher Scientific, Waltham, MA). We then added $20 \mu \mathrm{L}$ of the culture to $180 \mu \mathrm{L}$ of $\mathrm{CDM}\left(0.1 \% \mathrm{~K}_{2} \mathrm{HPO}_{4}, 0.1 \%\right.$ $\mathrm{KH}_{2} \mathrm{PO}_{4}, 0.5 \%$ yeast extract, $0.025 \% \mathrm{MgSO}_{4}, 0.005 \%$ $\mathrm{NaCl}$, and $0.1 \%$ glucose, $\mathrm{pH} 7.0$ ) supplemented with MPL at different concentrations (0, 0.5 , and $1 \%)$. Growth rates were determined in 96-well flat-bottomed plates (Corning Inc., Corning, NY) by $\mathrm{OD}_{600 \mathrm{~mm}}$, using the microplate reader at $37^{\circ} \mathrm{C}$ for $15 \mathrm{~h}$ with readings at 1-h intervals. Symbioflor (Enterococcus faecalis; SymbioPharm GmbH, Herborn, Germany), a commercial probiotic strain, was used as a positive control. The kinetic growth analysis was performed using a regression analysis in Python (Hoeflinger et al., 2017; https: //github.com/jlhoeflinger/RegressionAnalysisTool). The lag time $(\mathrm{h})$, the maximum specific growth rate $\left(\boldsymbol{\mu}_{\max }\right.$, per h), and the change in $\mathrm{OD}_{600 \mathrm{~nm}}\left(\boldsymbol{\Delta} \mathbf{O D}_{600 \mathrm{~nm}}\right)$ were obtained.

\section{Functional Characteristics of $L A B$}

The LAB selected were pre-grown with or without MPL and evaluated for their probiotic properties in vitro using the following tests.

\section{Survival in Acidic Conditions and Bile Salts}

The overnight culture of each bacterium in MRS broth was incubated at $37^{\circ} \mathrm{C}$. The bacterial pellet was obtained after centrifugation at 8,000 $\times g$ for $10 \mathrm{~min}$ at $4^{\circ} \mathrm{C}$. The pellet was washed 2 times and resuspended in 
$1 \mathrm{~mL}$ of SSS. Fresh CDM supplemented with MPL (0 and $0.5 \%$ ) was inoculated using $1 \%$ of the bacterial suspension. After $8 \mathrm{~h}$ of incubation, the cells were washed 4 times with SSS, and the bacterial concentration was adjusted to $10^{9} \mathrm{cfu} / \mathrm{mL}$.

The $\mathrm{pH}$ of $5 \mathrm{~mL}$ of MRS broth was adjusted to $\mathrm{pH}$ 2.5 and 3 using $1 \mathrm{~N} \mathrm{HCl}$ to perform the $\mathrm{pH}$ tolerance assay. To determine tolerance to bile salts, 2 concentrations of bile salts $(0.5$ or $1.0 \% ; 50 \%$ sodium cholate and $50 \%$ sodium deoxycholate; cat. no. B8756, SigmaAldrich, St. Louis, MO) in MRS broth were used. Each medium was inoculated with $10^{7} \mathrm{cfu} / \mathrm{mL}$ and incubated at $37^{\circ} \mathrm{C}$ for $4 \mathrm{~h}$. Afterward, $1 \mathrm{~mL}$ of each sample was serially diluted in SSS for spreading in MRS agar plates and incubated at $37^{\circ} \mathrm{C}$ for 24 to $48 \mathrm{~h}$. The results were expressed as a percentage of survival, using the growth of each strain at pH 7.0 in MRS medium without bile salts as controls (Vidhyasagar and Jeevaratnam, 2013).

\section{Auto-Aggregation and Cell Surface Hydrophobicity}

The auto-aggregation (AA) assay was adapted with some modifications from Sirichokchatchawan et al. (2018). Each strain was grown in CDM with or without MPL, as described previously. The bacterial suspension in SSS was adjusted to 0.6 of $\mathrm{OD}_{600 \mathrm{~nm}}$ using a microplate reader. For auto-aggregation, $5 \mathrm{~mL}$ of each bacterium suspension $\left(\mathrm{A}_{0-\mathrm{h}}\right)$ was mixed for $10 \mathrm{~s}$ and incubated at $37^{\circ} \mathrm{C}$ for each time point 1,2 , and $3 \mathrm{~h}\left(\mathrm{~A}_{\text {final-h }}\right)$. An aliquot of $1 \mathrm{~mL}$ of supernatant was taken, and the $\mathrm{OD}_{600 \mathrm{~nm}}$ was measured. Percentage of auto-aggregation was calculated as follows: $\% \mathrm{AA}=\left(1-\mathrm{A}_{\text {final-h }} / \mathrm{A}_{0 \mathrm{-h}}\right)$ $\times 100$ (Xu et al., 2009). For the cell surface hydrophobicity (CSH) assay, $1 \mathrm{~mL}$ of toluene (J. T. Baker, Phillipsburg, NJ) was added to $3 \mathrm{~mL}$ of each bacterium suspension $\left(\mathrm{OD}_{600 \mathrm{~nm}}=0.6\right)$ and mixed by vortexing for $90 \mathrm{~s}$. The samples were incubated for $30 \mathrm{~min}$ at $37^{\circ} \mathrm{C}$. Afterward, the $\mathrm{OD}_{600 \mathrm{~nm}}$ of the aqueous phase was measured. Percentage of CSH was calculated as follows: $\% \mathrm{CSH}=\left[\left(\mathrm{OD}_{600 \mathrm{~nm} \text { before mixing }}-\mathrm{OD}_{600 \mathrm{~nm} \text { after mixing }}\right) /\right.$ $\left.\left(\mathrm{OD}_{600 \mathrm{~nm} \text { before mixing }}\right)\right] \times 100$ (Ekmekci et al., 2009). The assays were performed in triplicate.

\section{Antibiotic Susceptibility}

The disk diffusion method was used to evaluate the antibiotic susceptibility of each strain pre-grown in CDM supplemented with or without MPL (0.5\%). The final antibiotic concentrations used were ampicillin $(10 \mu \mathrm{g})$, chloramphenicol $(30 \mu \mathrm{g})$, clindamycin $(2 \mu \mathrm{g})$, erythromycin $(15 \mu \mathrm{g})$, kanamycin $(30 \mu \mathrm{g})$, streptomycin $(300 \mu \mathrm{g})$, tetracycline $(30 \mu \mathrm{g})$, and vancomycin $(30$ $\mu \mathrm{g})$. All of these were purchased from Sigma-Aldrich (Faghfoori et al., 2017). The LAB strains were grown to
$10^{8} \mathrm{cfu} / \mathrm{mL}$, and $10 \mu \mathrm{L}$ was plated on MRS agar. Each antibiotic concentration was added to the disk, dried, placed on the surface of MRS plates, and incubated for $2 \mathrm{~h}$ at $4^{\circ} \mathrm{C}$ to facilitate the diffusion of antibiotics. The plates were incubated at $37^{\circ} \mathrm{C}$ for $24 \mathrm{~h}$. Finally, susceptibility to the antibiotics was measured by the inhibition zone and expressed in the following terms: $\mathrm{S}$ $=$ sensitive (zone diameter $\geq 1.7 \mathrm{~cm}$ ); $\mathrm{MS}=$ moderately sensitive (zone diameter 1.2 to $1.7 \mathrm{~cm}$ ); $\mathrm{R}=$ resistant (zone diameter $\leq 1.2 \mathrm{~cm}$; Faghfoori et al., 2017). The assays were performed in triplicate with 3 independent experiments.

\section{Hemolytic Activity}

Hemolytic activity was evaluated using Columbia agar plates with 5\% (vol/vol) sheep blood (Difco). Each LAB was grown in CDM with MPL (0 and $0.5 \%)$, incubated for $12 \mathrm{~h}$ at $37^{\circ} \mathrm{C}$, and plated on Columbia agar plates. The plates were incubated for 24 to 48 $\mathrm{h}$ at $37^{\circ} \mathrm{C}$ (Zoumpopoulou et al., 2018). Results were positive for $\beta$-hemolysis if a clear zone was observed around the colonies.

\section{Gene Detection Involved in Adhesion, Aggregation, Virulence Factors, and Biogenic Amines}

The LAB strains were tested for the presence of genes involved in adhesion and aggregation by PCR following the protocols described by de Souza et al. (2019). The genes evaluated include the following: ace (adhesion of collagen), agg (aggregation substance), asa1 (aggregation substance), EF 2662-cbp (cholinebinding protein), cylA (cytolysin), efaA (endocarditis antigen), esp (enterococcal surface), EF 1249-fbp (fibrinogen-binding protein), gelE (gelatinase), hdc (histidine decarboxylase), hyl (hyaluronidase), F 2380-maz (membrane-associated zinc metalloprotease), odc (ornithine decarboxylase), and $t d c$ (tyrosine decarboxylase). The PCR reactions were performed using an FX96 Touch Real-Time PCR Detection System (Bio-Rad, Hercules, CA). Amplicon visualization was performed with SYBER safe DNA gel stain (Invitrogen, Carlsbad, CA) under ultraviolet light after electrophoresis in 0.8 to $2.0 \%$ agarose gels. The ChemiDoc system (Bio-Rad) was used for image analysis.

\section{RNA Extraction and cDNA Synthesis}

After each LAB was grown in CDM with MPL (0 and $0.5 \%$ ), the bacterial pellet was recovered as previously described. Two milliliters of each bacterial culture was used for RNA extraction. Isolation of RNA was performed using the RNeasy Plus Mini Kit (Qiagen, 
Hilden, Germany) following the manufacturer's instructions. The iScript RT kit (Bio-Rad) was used to synthesize cDNA from $1 \mathrm{mg}$ of RNA.

\section{Real-Time Quantitative PCR}

The changes in gene expression were measured by quantitative PCR methods. Real-time PCR was performed using iTaq Universal SYBR Green Supermix (Bio-Rad) in a CFX96 Touch System. The gene expression levels of cell and mucus-binding protein A (CmbA), collagen-binding protein ( $\mathrm{Cnb})$, adhesion-like factor (EF-Tu), mucus adhesion-promoting protein (MapA), mucus-binding protein $(\mathrm{MuB})$, and surface layer protein (Slp) were normalized with the housekeeping gene 16S rRNA (Walter et al., 2001; Miyoshi et al., 2006; Hsueh et al., 2010; MacKenzie et al., 2010; Jensen et al. 2014). Relative gene expression changes are reported as the fold changes compared with the control samples (without MPL). Analysis was performed using CFX Maestro Software 3.1 (Bio-Rad). All experiments were performed in triplicate.

\section{Caco-2 Cell Culture and Adhesion Assay}

After LAB were grown in CDM with or without MPL, adhesion ability of each strain was investigated using the human epithelial colorectal adenocarcinoma (Caco-2) cell line. The Caco-2 cell line (HTB37, American Type Culture Collection, Rockville, MD, passages 26-40) was grown in Dulbecco's modified Eagle medium (DMEM) containing $4.5 \mathrm{~g} / \mathrm{L}$ glucose and supplemented with $15 \%$ (vol/vol) heat-inactivated fetal bovine serum (FBS), 1\% nonessential amino acids, 1\% L-glutamine, and $1 \%$ penicillin-streptomycin (all reagents from Gibco, Thermo Fisher Scientific). The cells were incubated in a humidified atmosphere of air $/ \mathrm{CO}_{2}(95: 5 \mathrm{vol} / \mathrm{vol})$ at $37^{\circ} \mathrm{C}$. The Caco- 2 cells were maintained in T-75 $\mathrm{cm}^{2}$ flasks (Corning) at $2 \times 10^{5}$ cells and grown for 4 to 6 d; they were split when they reached 70 to $90 \%$ confluence, using $0.05 \%$ trypsin and $0.5 \mathrm{~m} M$ EDTA (Gibco, Thermo Fisher Scientific). Cells were subcultured to 1 $\times 10^{5}$ cells per well in 12 -well culture plates (Corning) and cultured for 11 to $14 \mathrm{~d}$ post-confluency, a period at which they are highly differentiated and appropriate for experimental treatments. The FBS content was decreased to $7.5 \%$ (vol/vol) once cultures reached confluency (Chitchumroonchokchai et al., 2004). The medium was refreshed every $48 \mathrm{~h}$.

Before the bacteria were added, the medium of each well was removed, and the monolayer of Caco-2 cells was washed 2 times with fresh FBS-free DMEM. Bacterial cultures of each strain in CDM with and without MPL were grown for 8 to $9 \mathrm{~h}$ at $37^{\circ} \mathrm{C}$. The cells were centrifuged at $1,700 \times g$ for 5 min at $4^{\circ} \mathrm{C}(5804 \mathrm{R}$ centrifuge, Eppendorf). The bacterial pellet was washed 4 times with calcium- and magnesium-free PBS (DPBS, Corning) and finally resuspended in fresh antibioticand FBS-free DMEM to achieve $1 \times 10^{8} \mathrm{cfu} / \mathrm{mL}$. The Caco-2 cells were cocultured with $1 \mathrm{~mL}$ of bacteria suspension and were incubated for $3 \mathrm{~h}$ in a humidified atmosphere of air and $\mathrm{CO}_{2}(95: 5, \mathrm{vol} / \mathrm{vol})$ at $37^{\circ} \mathrm{C}$. The supernatant was aspirated to remove nonadhering bacteria. Each well was rinsed 3 times with $1 \mathrm{~mL}$ of DPBS. To release attached bacteria, each well was treated with $1 \mathrm{~mL}$ of $1 \%$ (vol/vol) Triton X-100 (Sigma-Aldrich) in DPBS and incubated at $4^{\circ} \mathrm{C}$ for $30 \mathrm{~min}$. The bacteria recovered from each well were transferred to sterilized $1.5-\mathrm{mL}$ tubes, centrifuged at $8,000 \times g$ for $10 \mathrm{~min}$ at $4^{\circ} \mathrm{C}$, and washed 2 times with $1 \mathrm{~mL}$ of DPBS. Finally, the adhered cells were resuspended in DPBS, and serial dilutions were used to inoculate in MRS agar and incubated under anaerobic conditions at $37^{\circ} \mathrm{C}$ for $48 \mathrm{~h}$ to determine the viable cell number. The results correspond to the mean of 3 independent experiments and were expressed as percent of adhesion with respect to the initial population added per well (Lee et al., 2014).

\section{Statistical Analysis}

A one-way ANOVA was performed, followed by least significant difference test, and paired $t$-tests were applied to detect significant difference $(P<0.05)$.

\section{RESULTS AND DISCUSSION}

\section{Growth Kinetics of LAB in Milk Phospholipids}

Lactic acid bacteria belong to a complex, heterogeneous group of microorganisms. Extensive culture media have been developed for cultivation of LAB. The most suitable and most commonly used medium is MRS broth, due to the high concentration of its components (de Man et al., 1960; Schillinger and Holzapfel, 2003). These components include proteose peptone, meat extract, yeast extract, and glucose, as they provide bacteria with sources of nitrogen, carbon, vitamins, and minerals. Polysorbate 80, sodium magnesium, and manganese salts provide growth cofactors, and the sodium citrate can inhibit undesirable gram-negative bacteria (Reuter, 1985). Moreover, other limited culture media have been designed to analyze and quantify specific molecules, because complex media can interfere in analytical analyses (Wegkamp et al., 2010; Aller et al., 2014). In this work, we used a chemically defined medium that contains a low nutrient concentration compared with MRS medium and was supplemented with milk phospholipids. Figure 1 shows the growth 
kinetics of each strain at 2 MPL concentrations: 0.5 and $1.0 \%$. In general, LAB in either MPL concentration experienced decreased lag time and $\mu_{\max }$, and increased $\Delta \mathrm{OD}_{600 \mathrm{~nm}}$, compared with the control (without MPL). The OSU-PECh-C strain exhibited no difference in $\mu_{\max }$ or $\Delta \mathrm{OD}_{600 \mathrm{~nm}}$ between MPL-containing and MPLlacking media. In the presence of $1 \% \mathrm{MPL}, L$. reuteri (OSU-PECh-48) and E. faecalis had the greatest $\mu_{\max }$ values $(0.07 / \mathrm{h})$ compared with the $0 \% \mathrm{MPL}$ controls, as well as the highest $\Delta \mathrm{OD}_{600 \mathrm{~nm}}$ values (0.44). In $0.5 \%$ MPL, higher $\mu_{\max }$ values and lower lag time values were obtained for all the strains. These trends suggest that the best adaptation to the minimal culture medium supplemented with MPL was at $0.5 \%$ MPL. Therefore, this concentration was used for all further experiments. Under specific environmental conditions, LAB can modify their metabolism to increase their survival. During the logarithmic stage of growth, bacteria are highly metabolically active (gene, protein, and enzyme synthesis). Thus, it is postulated that the bacteria able to grow in MPL may increase their odds of survival and prevalence during gastrointestinal transit compared with bacteria that are incapable of acclimating to MPL.
The mechanism of phospholipid utilization by LAB is through interactions with their cell walls, teichoic or lipoteichoic acids, and S-layer proteins (Sleytr et al., 2014). Given that the main distinction between phospholipids and other lipids (such as triglycerides) is the presence of a polar head group, PL attachment to LAB is likely dependent on the properties of the polar head group. However, more hydrophobic bacterial strains exhibit greater binding incidence. Several studies on the cell surface of LAB have shown that the presence of proteins and glycoproteins enhance hydrophobicity properties (Kos et al., 2003). The S-layer proteins in LAB are usually highly basic $(\mathrm{pH}>9.4)$ due to their greater proportions of positively charged amino acid residues. These cationic residues (e.g., lysine or arginine) are suggested to interact with PL head groups possessing an anionic charge (Smit et al., 2001). Therefore, the binding of LAB to MPL in this experiment may be occurring between positively charged amino acid residues and some negatively charged segments of the phospholipid, including the phosphate group and the polar head group. This interaction could be with PS or with PI, or both, because both PL contain an-
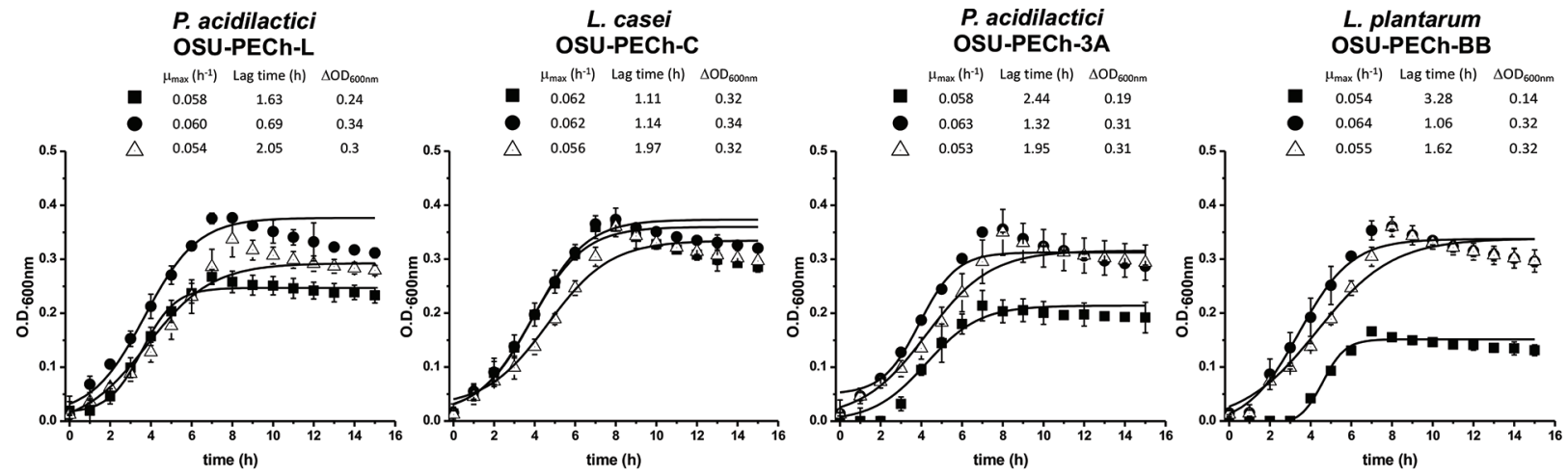

- $0 \% \mathrm{MPL}$

L. paracase $i$ OSU-PECh-3B
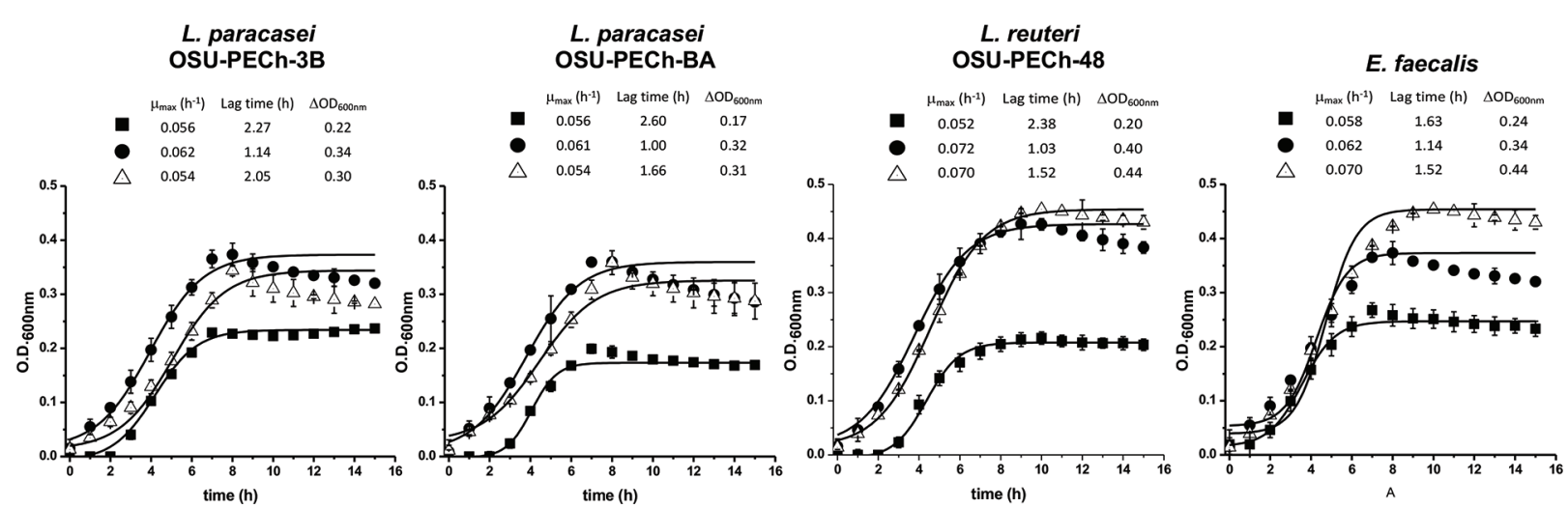

$0.5 \% \mathrm{MPL}$
$\triangle 1.0 \% \mathrm{MPL}$

Figure 1. Kinetic growth of lactic acid bacteria in chemically defined medium with 0.0 (squares), 0.5 (circles), or $1.0 \%$ (triangles) milk

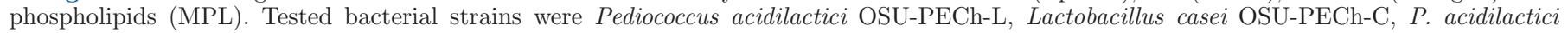

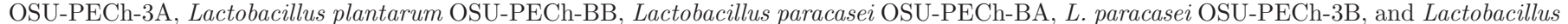

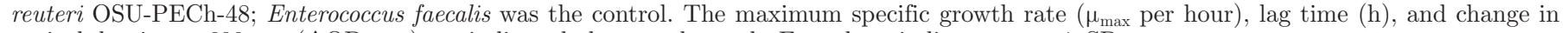
optical density at $600 \mathrm{~nm}\left(\Delta \mathrm{OD}_{600 \mathrm{~nm}}\right)$ are indicated above each graph. Error bars indicate mean $\pm \mathrm{SD}$. 
ionic polar head groups. Binding of MPL to LAB also depends of the quantity of S-layer proteins that have been reported. Different proportions of these proteins between strains affect the interaction (Roos and Jonsson, 2002; Frece et al., 2005).

\section{Functional Characteristics of $L A B$}

Acidic pH, Bile Salt Tolerance, Auto-Aggregation, and Cell Surface Hydrophobicity. All LAB strains were subject to assessment of their functional characteristics in the presence of MPL to estimate their potential for food use and survival in the gastrointestinal tract (GIT). Only 3 strains exhibited tolerance at $\mathrm{pH} 2.5,2$ strains showed less than $5 \%$ survival, and 3 others did not survive at $\mathrm{pH} 2.5$. However, at $\mathrm{pH} 3$, all of the tested strains were tolerant, with over $60 \%$ survival. Generally, supplementation of MPL in the medium did not increase LAB survival in acidic $\mathrm{pH}$ conditions. Only OSU-PECh-L showed an increased survival percentage at $\mathrm{pH} 2.5$ with MPL supplementation, compared with the MPL-lacking control. On the other hand, E. faecalis did not survive at $\mathrm{pH} 2.5$ under either condition (Figure 2A). Evaluation of survival at acidity levels similar to those of the GIT is one factor for consideration of a $\mathrm{LAB}$, as probiotic potential is also related to the surface properties of the bacteria, which determines their ability to adhere to the mucosal surfaces of the intestine (Argyri et al., 2013). It has been described that the benefits of probiotics on human health correlate with their effects in the large intestine, such as excluding adhesion of pathogenic bacteria in the gut, protecting the epithelial barrier, and immunomodulatory effects (de Vries et al., 2006).

These surface properties can be measured by bile salt tolerance, AA, and CSH. Bile salt tolerance helps predict the prevalence and survival of probiotic bacteria in the GIT (Gómez Zavaglia et al., 2002). All bacteria tested survived at 0.5 and $1.0 \%$ bile salts, with or without MPL. The P. acidilactici OSU-PECh-3A strain showed the highest percentage of survival in $0.5 \%$ bile salts when the bacterium was pre-grown in MPL. In $1 \%$ bile salts, no bacteria showed differences in survival between conditions with or without MPL (Figure 2B). In the human body, bile salt concentration is around 0.3 to $0.4 \%$. Bacterial cells unable to resist this concentration have altered membrane permeability and reduced survival due to disruption of the bacterial membrane and DNA damage (Ruiz et al., 2013; García-Ruiz et al., 2014). However, it had been reported that Streptococcus thermophilus can resist bile salts due to activation of different surface proteins, such as sortase-dependent proteins, which maintain the bacterial membrane integrity (Kebouchi et al., 2016). Figure 2C shows the increase in AA after $3 \mathrm{~h}$ of incubation with and without MPL. All of the bacteria exhibited AA between 25 and $45 \%$; OSU-PECh-BB, OSU-PECh-BA, OSU-PECh3B, OSU-PECh-48, and E. faecalis had AA values over $50 \%$ without previous incubation with MPL. However, after each bacterium was preincubated with MPL, AA behavior decreased with no significant difference. The AA of the tested bacteria varied between strains, suggesting potential differences in ability of these strains to bind to the intestinal epithelium. Previous reports have shown that high AA values for $L$. reuteri correlate with high adhesion to Caco-2 cells (Singh et al., 2016).

Cell surface hydrophobicity was evaluated for the 7 LAB strains and the control. hydrophobicity was above $30 \%$ for all strains. Lactobacillus reuteri OSU-PECh- 48 showed the highest percentage of $\mathrm{CSH}$ (Figure 2D). Similar trends to the AA assay data were observed for CHS. When bacteria were pre-grown in MPL, CHS decreased with no significant difference. It has been reported that the bacterial cell surface contains glycoproteins, which contribute to their hydrophobic properties. Hydrophobic effects are also correlated with ability to adhere to the GIT (Singh et al., 2016).

Antibiotic Susceptibility and Gene Detection of Virulence Factors. Antibiotic resistance of probiotic strains is of concern because genetic elements carrying resistance genes are mobile and, as such, can potentially be transmitted to pathogens. The $7 \mathrm{LAB}$ strains isolated did not show a difference in antibiotic resistance with or without MPL (Table 1). In general, Lactobacillus are susceptible to antibiotics such as erythromycin, chloramphenicol, clindamycin, and tetracycline, which inhibit protein synthesis (Ammor et al., 2007). All of the LAB strains presented were resistant to vancomycin. This resistance is typically found in the Lactobacillus genus encoded by chromosomic genes. Because this resistance gene is located within the chromosome, it is not transferable to pathogens (Divya et al., 2012). Some virulence factor genes were detected in OSU-PECh-BB, OSU-PECh-3B, OSUPECh-48, and the E. faecalis strains. In all cases, the frequency of detection of these genes was lower than in other strains isolated from foods and clinical settings (Martín-Platero et al., 2009). Virulence factors can stay in a silenced state, wherein the gene is present but needs a regulation system to be activated and express itself. These genes are not expressed under laboratory conditions but can be expressed in vivo, suggesting that the pathogenicity potential should be carefully considered (Martín-Platero et al., 2009).

Gene Expression Analysis. After each bacterium was grown in MPL (0 and $0.5 \%$ ), the total RNA was extracted and used for quantitative PCR analysis. Gene expression profiling analysis is shown in the heat 
map, where the gene expression values show the high (red), low (green), and nonsignificant (black) expression levels (Figure 3). We found that OSU-PECh-L was the strain that showed highest gene expression of all the genes evaluated, and OSU-PECh-BA strain did not show significant different gene expression in 5 of the 6 genes evaluated. We found that OSU-PECh-3B showed high levels of gene expression in $C n b, E F-T u, M u b$, and Slp; also, OSU-PECh-48 showed high gene expression in $C m b A, C n b, M a p A$, and $M u b$.

Many bacterial cell surface proteins can interact with mucins, proteins, phospholipids, and carbohydrates (Naughton et al., 2014; Guerin et al., 2018). In addition to the ability of LAB to grow in MPL, biochemical changes in the bacterial cell membrane may occur. Surface proteins that may be involved are mucus-binding proteins - for instance, CmbA, MapA, and Mub. In vitro experiments have demonstrated that these proteins increase the binding of LAB to intestinal cells and mucus (Jensen et al., 2014). The CmbA protein in L. reuteri 6475 is important to enhanceing adhesion to Caco-2 cells, because the mutants of this gene showed significant loss of adhesion (Jensen et al., 2014). On the other hand, $M u b$ and $M a p A$ are down- and upregulated under specific conditions. In the presence of mucus, these genes are positively expressed in $L$. plantarum 423; however, under pancreatin conditions, the $M u b$ gene is downregulated and MapA is upregulated (Ra-
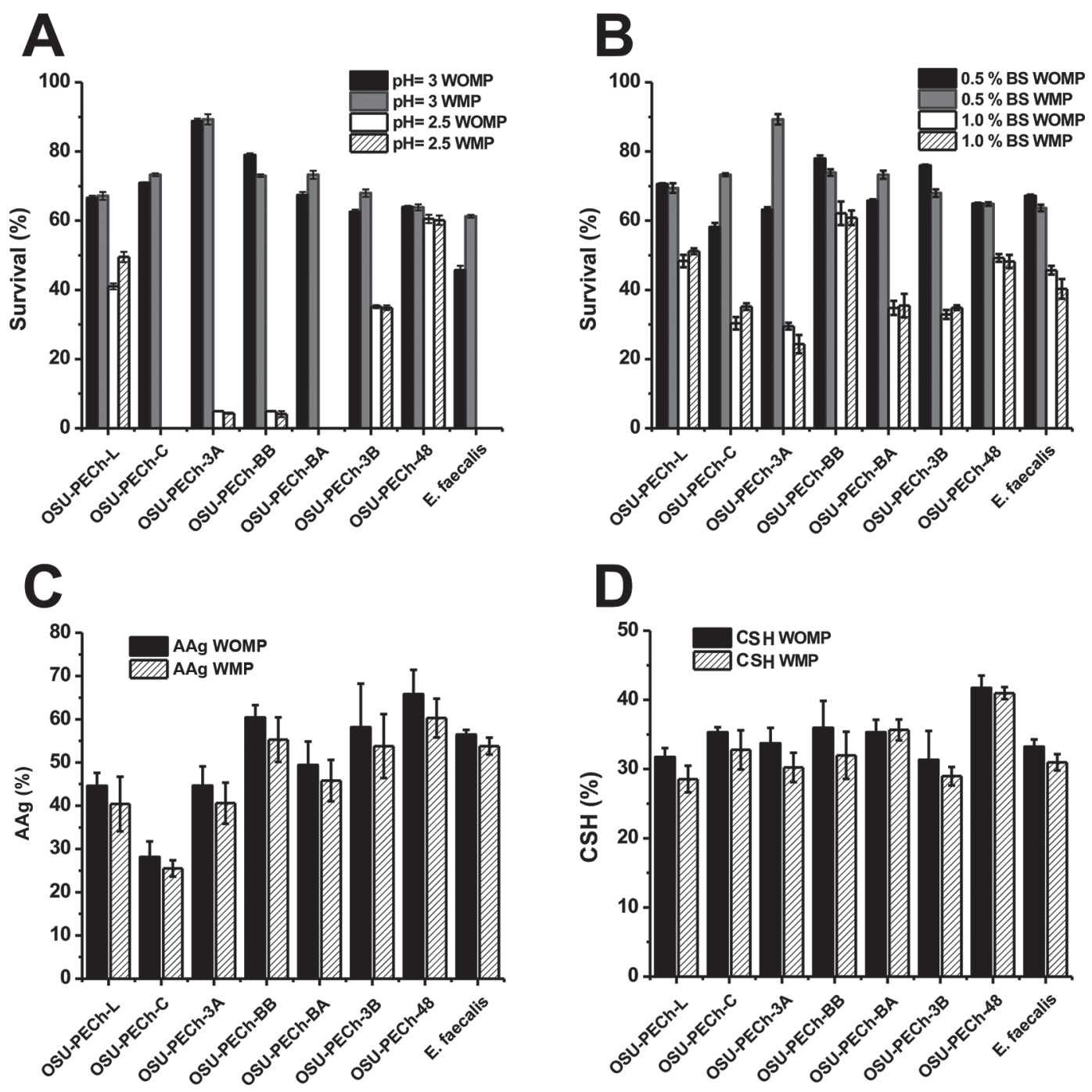

Figure 2. Assessment of probiotic profiles of tested bacterial strains Pediococcus acidilactici OSU-PECh-L, Lactobacillus casei OSU-PECh-C, P. acidilactici OSU-PECh-3A, Lactobacillus plantarum OSU-PECh-BB, Lactobacillus paracasei OSU-PECh-BA, L. paracasei OSU-PECh-3B, and Lactobacillus reuteri OSU-PECh-48; Enterococcus faecalis was the control. (A) Acidic pH tolerance at pH 2.5 and pH 3 with (WMP) and without milk phospholipids (WOMP); (B) bile salt (BS) tolerance at concentrations of $0.5 \%$ and 1.0\%; (C) auto-aggregation (AAg) over 3 h; (D) cell surface hydrophobicity (CSH). Error bars indicate mean \pm SD. 


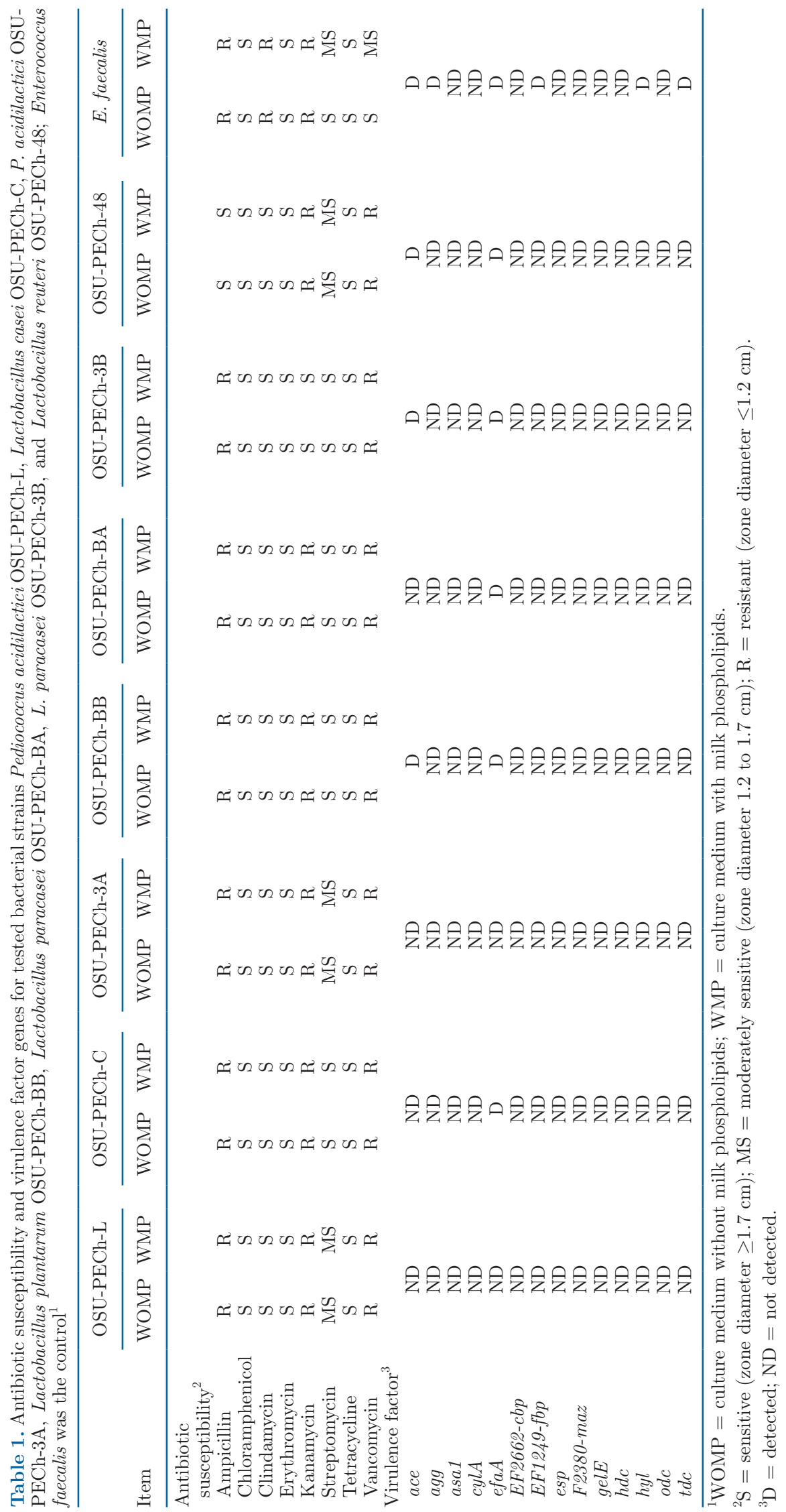



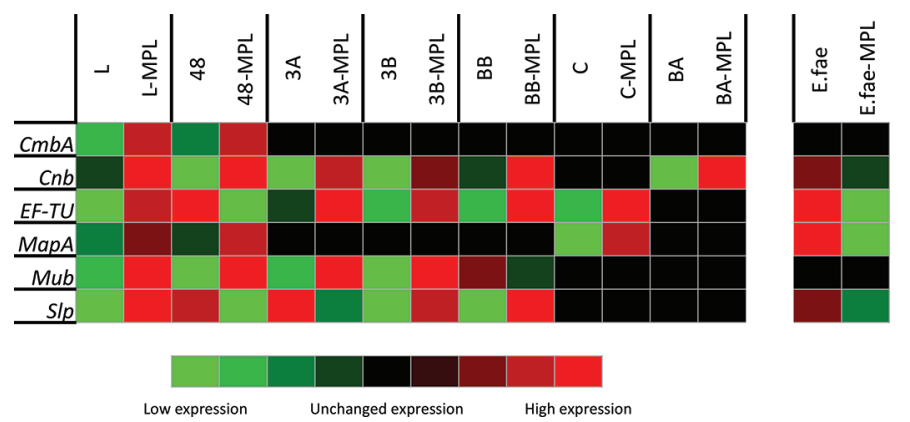

Figure 3. Heat map of gene expression of tested bacterial strains Pediococcus acidilactici OSU-PECh-L, Lactobacillus casei OSUPECh-C, P. acidilactici OSU-PECh-3A, Lactobacillus plantarum OSU-PECh-BB, Lactobacillus paracasei OSU-PECh-BA, L. paracasei OSU-PECh-3B, and Lactobacillus reuteri OSU-PECh-48; Enterococcus faecalis was the control. Left column: $C m b A$ (cell and mucus-binding protein A); $C n b$ (collagen-binding protein); $E F$ - Tu (adhesion-like factor); MapA (mucus adhesion-promoting protein); $M u B$ (mucus-binding protein); $S l p$ (surface-layer protein). Top row: each bacterium pregrown with and without milk phospholipids (MPL). Red $=$ high gene expression; green $=$ low gene expression; black $=$ nonsignificant change in gene expression.

miah et al. 2009). In this study, we can assume that the proteins CmbA, MapA, and Mub can be expressed in the presence of MPL and can enhance adhesion to the Caco-2 cell line. Some surface proteins, such as Cnb and Slp, play an important role in bacterial cell adhesion to the human gut (Deepika and Charalampopoulos, 2010; Hsueh et al., 2010). For instance, Cnb was expressed in L. casei ATCC 393, showing high adherence to Caco-2 cells, even displaying better adhesion than pathogenic strains (Hsueh et al., 2010). It has been reported in L. acidophilus that 2 genes that express Slp proteins have been deleted, resulting in decreased binding and adherence to epithelial cell in vitro, which suggests their important role in intestinal adhesion (Buck et al., 2005; Goh et al., 2009). Also, the EF-Tu gene has been described as an adhesion-like factor protein, which plays an important role in attaching the bacterial cell to mucin. Like other types of surface proteins, the EF-Tu gene is regulated under some conditions. In L. acidophilus ATCC 4356, this gene was upregulated in bile and pancreatin conditions, suggesting that this strain can adapt in the lower intestinal tract (Ramiah et al., 2009).

Adhesion to Caco-2 Cells. In this study, the adhesion of LAB isolated from different dairy products to a human enterocyte-like cell line (Caco-2) was evaluated. Figure 4 shows the adhesion of the bacterial strains previously grown in media with and without MPL to Caco- 2 cells. The strains $L$. plantarum OSU-PECh-BB and $L$. reuteri OSU-PECh- 48 had the greatest adhesion when grown in MPL, even compared with the commercial control (E. faecalis). Pediococcus acidilactici
OSU-PECh-L grown in MPL had significantly greater adherence than when it was grown without MPL; however, its adhesion was lower than the 2 high-adhering strains. The behavior differs from the reports for $L$. rhamnosus GG supplemented with MFGM, which may be explained by the different compositions of MFGM and MPL. The MPL used in this study contains a low protein concentration (K. Wang, 2018, The Ohio State University, Columbus, personal communication), which may favor an interaction between bacteria and Caco-2 cells (Costa et al., 2010; Cheng et al., 2019). However, it has been proposed that the presence of MFGM may hinder the adhesion process of L. rhamnosus GG to Caco-2 cells, reducing the beneficial effects of probiotic adherence to the human gut (Guerin et al., 2019). The MFGM is a complex matrix composed of triglycerides, phospholipids, sphingolipids, and glycoproteins (membrane-specific proteins). The strains OSU-PECh-C, OSU-PECh-3A, OSU-PECh-BA, and OSU-PECh-3B did not show significant differences in adhesion when grown with or without MPL, although, these strains still exhibited over $85 \%$ adhesion (Figure 4).

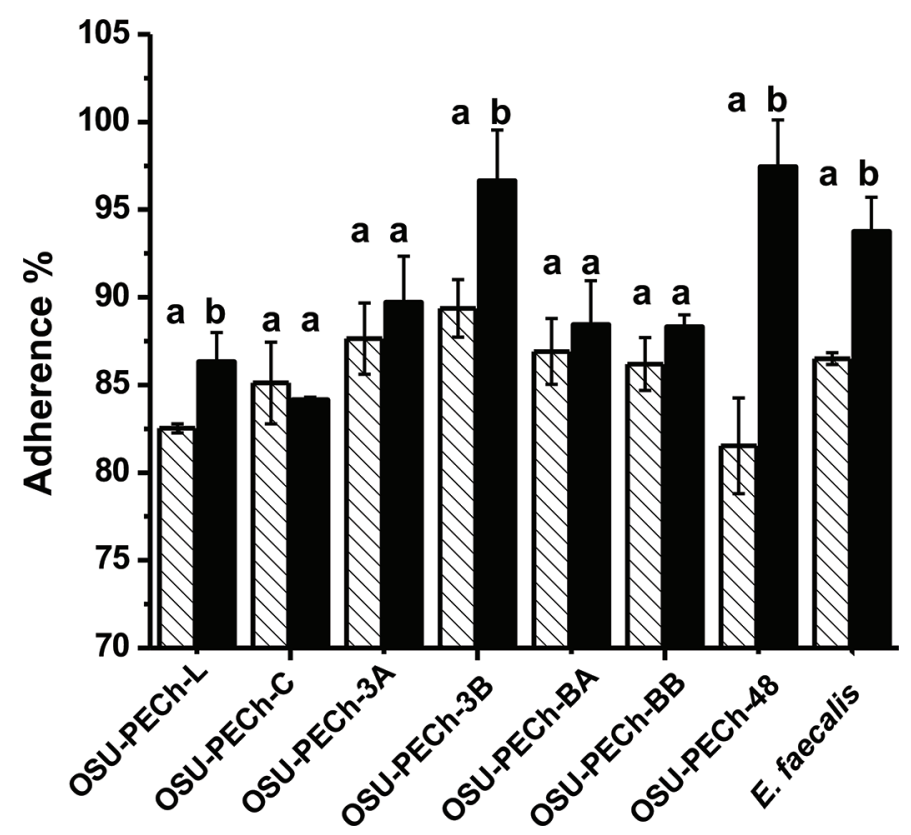

Figure 4. Adhesion of 7 lactic acid bacteria strains, isolated from dairy products, to Caco-2 cells. Tested bacterial strains were Pediococcus acidilactici OSU-PECh-L, Lactobacillus casei OSUPECh-C, P. acidilactici OSU-PECh-3A, Lactobacillus plantarum OSU-PECh-BB, Lactobacillus paracasei OSU-PECh-BA, L. paracasei OSU-PECh-3B, and Lactobacillus reuteri OSU-PECh-48; Enterococcus faecalis was the control. Semi-filled bars $=$ adherence of each bacteria without milk phospholipids (MPL); filled bars = adherence of each bacteria with $0.5 \%$ MPL. Error bars represent SD of 6 independent experiments. Different lowercase letters $(\mathrm{a}, \mathrm{b})$ indicate significance differences $(P<0.05)$ in comparison of bacterial growth with and without MPL. Error bars indicate mean \pm SD. 
The ability of bacterial cells to adhere to human intestinal cells can be used as a predictor for maintaining a healthy gut microbiome, which can provide protection against gastrointestinal disorders, including inflammatory bowel diseases, cancer, and gastrointestinal infections (Singh et al., 2011). The mechanism of action of probiotics involves antagonizing pathogens through the production of antimicrobial compounds such as lactic acid, acetic acid, hydrogen peroxide, bacteriocins, and peptidoglycan hydrolases (Buffie and Pamer, 2013). Additionally, probiotic bacteria can provide other benefits, such as preventing the adhesion of pathogenic microorganisms that compete for host-cell binding sites.

The identity and concentrations of MPL components were analyzed in the culture media by HPLC (data not shown). The composition of the PL species of the MPL starting material showed the following order of abundance: $\mathrm{PC}>\mathrm{SM}>\mathrm{PE}>\mathrm{PI}>\mathrm{PS}$, which mirrors reports by other authors (Morifuji et al., 2017). After the fermentation process for each strain, a nonsignificant change in concentration was observed for PL species. The lack of major changes in PL composition may be attributable to the high degree of regulation of cellular and intracellular membranes by LAB. Additionally, PL can be interconverted between one another to meet the requirements for membrane fluidity. For instance, SM includes a choline group linked to the ceramide group. The choline from SM can be used for PC synthesis. Syntheses of PE, PS, and PC are also connected via glycerophospholipid synthesis pathways (such as the Kennedy pathway), which serves as a mechanism to maintain the membrane.

Many reports have described the numerous benefits of MPL. For example, PC (being the most abundant phospholipid in bacteria) has been reported to reduce the development of arthritis and increase the antiinflammatory response (Lordan et al., 2017). On the other hand, SM is the most abundant species of the sphingolipid group. Derived only from animal products such as milk, SM is composed of the metabolites sphingosine and ceramide. These metabolites have several benefits in the gut, as they can modulate growth factors, which maintain membrane structure, as well as inhibit cell proliferation and induce apoptosis (Vesper et al., 1999). Both PE and PS are also present in bacterial membranes (Gorby et al., 1988). The combination of PS and SM has been shown to have beneficial effects on human memory and the acute stress response (Hellhammer et al., 2010).

The HPLC data to understand how the LAB utilize MPL were inconclusive (data not shown). Furthermore, bacteria are able to synthesize PL, which makes it difficult to differentiate between bacterially derived PL and the initial MPL in the culture medium. However, we observed that bacteria grown in the presence of MPL had greater adhesion to Caco-2 cells. Further studies are needed to clarify the potential underlying mechanism for this effect and also to determine which components from milk phospholipids (or the additive effect of all PL species at the ratio found in milk) increase the adhesion of LAB to intestinal cells.

\section{CONCLUSIONS}

This study demonstrated that fermentation of milk phospholipids by LAB increased bacterial adhesion to the human intestinal cells, a desirable characteristic of probiotics. Furthermore, the bacteria analyzed in this work hold potential for use as probiotics. However, it remains unclear which milk phospholipids are utilized by LAB, and further studies are needed to clarify this process. These findings show a potential advantage for dairy foods enriched in milk phospholipids (as by the addition of buttermilk), which may enhance the bacteria adhesion (probiotic or starters) and provide a direct benefit to the human gut. Our study sheds light on the increased binding ability of some LAB strains, which may extend the residence times of beneficial bacteria in the gut and, therefore, help improve the health and wellness of the microbiome of the human intestine.

\section{ACKNOWLEDGMENTS}

This study was funded by the Parker Endowment at The Ohio State University (Columbus, $\mathrm{OH}$; grant number 00100). We confirm that we do not have any conflict of interest.

\section{REFERENCES}

Aller, K., K. Adamberg, V. Timarova, A. Seiman, D. Feštšenko, and R. Vilu. 2014. Nutritional requirements and media development for Lactococcus lactis IL1403. Appl. Microbiol. Biotechnol. 98:5871-5881. https://doi.org/10.1007/s00253-014-5641-7.

Ammor, M. S., A. Belén Flórez, and B. Mayo. 2007. Antibiotic resistance in non-enterococcal lactic acid bacteria and bifidobacteria. Food Microbiol. 24:559-570. https://doi.org/10.1016/j.fm.2006.11 .001 .

Argyri, A. A., G. Zoumpopoulou, K. A. Karatzas, E. Tsakalidou, G.J. E. Nychas, E. Z. Panagou, and C. C. Tassou. 2013. Selection of potential probiotic lactic acid bacteria from fermented olives by in vitro tests. Food Microbiol. 33:282-291. https://doi.org/10.1016/ j.fm.2012.10.005.

Barrett, H. L., L. K. Callaway, and M. D. Nitert. 2012. Probiotics: A potential role in the prevention of gestational diabetes? Acta Diabetol. 49(Suppl. 1):S1-S13. https://doi.org/10.1007/s00592 -012-0444-8.

Buck, B. L., E. Altermann, T. Svingerud, and T. R. Klaenhammer. 2005. Functional analysis of putative adhesion factors in Lactobacillus acidophilus NCFM. Appl. Environ. Microbiol. 71:8344-8351. https://doi.org/10.1128/AEM.71.12.8344-8351.2005. 
Buffie, C. G., and E. G. Pamer. 2013. Microbiota-mediated colonization resistance against intestinal pathogens. Nat. Rev. Immunol. 13:790-801. https://doi.org/10.1038/nri3535.

Cheng, S., K. Rathnakumar, and S. I. Martínez-Monteagudo. 2019. Extraction of dairy phospholipids using switchable solvents: A feasibility study. Foods 8:265. https://doi.org/10.3390/foods8070265.

Chitchumroonchokchai, C., S. J. Schwartz, and M. L. Failla. 2004. Assessment of lutein bioavailability from meals and a supplement using simulated digestion and Caco-2 human intestinal cells. J. Nutr. 134:2280-2286. https://doi.org/10.1093/jn/134.9.2280.

Contarini, G., and M. Povolo. 2013. Phospholipids in milk fat: Composition, biological and technological significance, and analytical strategies. Int. J. Mol. Sci. 14:2808-2831. https://doi.org/10.3390/ ijms14022808.

Costa, M. R., X. E. Elias-Argote, R. Jiménez-Flores, and M. L. Gigante. 2010. Use of ultrafiltration and supercritical fluid extraction to obtain a whey buttermilk powder enriched in milk fat globule membrane phospholipids. Int. Dairy J. 20:598-602. https://doi .org/10.1016/j.idairyj.2010.03.006.

Currò, D., G. Ianiro, S. Pecere, S. Bibbò, and G. Cammarota. 2017. Probiotics, fibre and herbal medicinal products for functional and inflammatory bowel disorders. Br. J. Pharmacol. 174:1426-1449. https://doi.org/10.1111/bph.13632.

Danielsen, E. M., and G. H. Hansen. 2006. Lipid raft organization and function in brush borders of epithelial cells. Mol. Membr. Biol. 23:71-79. https://doi.org/10.1080/09687860500445604.

de Man, J. C., M. Rogosa, and M. E. Sharpe. 1960. A medium for the cultivation of lactobacilli. J. Appl. Bacteriol. 23:130-135. https:// doi.org/10.1111/j.1365-2672.1960.tb00188.x.

de Souza, B. M. S., T. F. Borgonovi, S. N. Casarotti, S. D. Todorov, and A. L. B. Penna. 2019. Lactobacillus casei and Lactobacillus fermentum strains isolated from mozzarella cheese: Probiotic potential, safety, acidifying kinetic parameters and viability under gastrointestinal tract conditions. Probiotics Antimicrob. Proteins 11:382-396. https://doi.org/10.1007/s12602-018-9406-y.

de Vries, M. C., E. E. Vaughan, M. Kleerebezem, and W. M. de Vos. 2006. Lactobacillus plantarum - Survival, functional and potential probiotic properties in the human intestinal tract. Int. Dairy J. 16:1018-1028. https://doi.org/10.1016/j.idairyj.2005.09.003.

Deepika, G., and D. Charalampopoulos. 2010. Chapter 4: Surface and adhesion properties of lactobacilli. In Advances in Applied Microbiology. Academic Press, Elsevier, San Diego, CA.

Divya, J. B., K. K. Varsha, and K. M. Nampoothiri. 2012. Newly isolated lactic acid bacteria with probiotic features for potential application in food industry. Appl. Biochem. Biotechnol. 167:13141324. https://doi.org/10.1007/s12010-012-9561-7.

Ekmekci, H., B. Aslim, and S. Ozturk. 2009. Characterization of vaginal lactobacilli coaggregation ability with Escherichia coli. Microbiol. Immunol. 53:59-65. https://doi.org/10.1111/j.1348-0421 2009.00115.x.

Faghfoori, Z., B. Pourghassem Gargari, A. Saber, M. Seyyedi, and A. Yari Khosroushahi. 2017. The investigation of the diversity of lactobacilli spp. and assessment their some probiotic properties in traditional dairy products in East Azerbaijan Province in Iran. Iran J. Pharm. Res. IJPR 16:1538-1545.

FAO/WHO (Food and Agriculture Organization and World Health Organization). 2006. Page 46 in Probiotics in food: Health and nutritional properties and guidelines for evaluation -. FAO Food Nutr. Pap. 85: http://www.fao.org/tempref/docrep/fao/009/ a0512e/a0512e00.pdf. Accessed Apr. 9, 2020.

Frece, J., B. Kos, I. K. Svetec, Z. Zgaga, V. Mrša, and J. Šušković. 2005. Importance of S-layer proteins in probiotic activity of Lactobacillus acidophilus M92. J. Appl. Microbiol. 98:285-292. https:// doi.org/10.1111/j.1365-2672.2004.02473.x.

García-Cano, I., D. Rocha-Mendoza, J. Ortega-Anaya, K. Wang, E. Kosmerl, and R. Jiménez-Flores. 2019. Lactic acid bacteria isolated from dairy products as potential producers of lipolytic, proteolytic and antibacterial proteins. Appl. Microbiol. Biotechnol. 103:5243-5257. https://doi.org/10.1007/s00253-019-09844-6.

García-Ruiz, A., D. González de Llano, A. Esteban-Fernández, T. Requena, B. Bartolomé, and M. V. Moreno-Arribas. 2014. Assess- ment of probiotic properties in lactic acid bacteria isolated from wine. Food Microbiol. 44:220-225. https://doi.org/10.1016/j.fm .2014.06.015.

Goh, Y. J., M. A. Azcárate-Peril, S. O'Flaherty, E. Durmaz, F. Valence, J. Jardin, S. Lortal, and T. R. Klaenhammer. 2009. Development and application of a $u p p$-based counterselective gene replacement system for the study of the S-layer protein SlpX of Lactobacillus acidophilus NCFM. Appl. Environ. Microbiol. 75:3093-3105. https: //doi.org/10.1128/AEM.02502-08.

Gómez Zavaglia, A., P. Kociubinski, P. Perez, E. Disalvo, and G. De Antoni. 2002. Effect of bile on the lipid composition and surface properties of bifidobacteria. J. Appl. Microbiol. 93:794-799. https: //doi.org/10.1046/j.1365-2672.2002.01747.x.

Gorby, Y. A., T. J. Beveridge, and R. P. Blakemore. 1988. Characterization of the bacterial magnetosome membrane. J. Bacteriol. 170:834-841. https://doi.org/10.1128/JB.170.2.834-841.1988.

Guerin, J., J. Burgain, F. Gomand, J. Scher, and C. Gaiani. 2019. Milk fat globule membrane glycoproteins: Valuable ingredients for lactic acid bacteria encapsulation? Crit. Rev. Food Sci. Nutr. 59:639651. https://doi.org/10.1080/10408398.2017.1386158.

Guerin, J., C. Soligot, J. Burgain, M. Huguet, G. Francius, S. ElKirat-Chatel, F. Gomand, S. Lebeer, Y. Le Roux, F. Borges, J. Scher, and C. Gaiani. 2018. Adhesive interactions between milk fat globule membrane and Lactobacillus rhamnosus GG inhibit bacterial attachment to Caco-2 TC7 intestinal cell. Colloids Surf. B Biointerfaces 167:44-53. https://doi.org/10.1016/j.colsurfb.2018 .03 .044 .

Hartmann, P., A. Szabó, G. Erős, D. Gurabi, G. Horváth, I. Németh, M. Ghyczy, and M. Boros. 2009. Anti-inflammatory effects of phosphatidylcholine in neutrophil leukocyte-dependent acute arthritis in rats. Eur. J. Pharmacol. 622:58-64. https://doi.org/10 .1016/j.ejphar.2009.09.012.

Hellhammer, J., A. Waladkhani, T. Hero, and C. Buss. 2010. Effects of milk phospholipid on memory and psychological stress response. Br. Food J. 112:1124-1137. https://doi.org/10.1108/ 00070701011080258

Hoeflinger, J. L., D. E. Hoeflinger, and M. J. Miller. 2017. A dynamic regression analysis tool for quantitative assessment of bacterial growth written in Python. J. Microbiol. Methods 132:83-85. https: //doi.org/10.1016/j.mimet.2016.11.015.

Hsueh, H. Y., P. Y. Yueh, B. Yu, X. Zhao, and J. R. Liu. 2010. Expression of Lactobacillus reuteri $\mathrm{Pg} 4$ collagen-binding protein gene in Lactobacillus casei ATCC 393 increases its adhesion ability to Caco-2 cells. J. Agric. Food Chem. 58:12182-12191. https://doi .org/10.1021/jf1035756.

Jensen, H., S. Roos, H. Jonsson, I. Rud, S. Grimmer, J.-P. van Pijkeren, R. A. Britton, and L. Axelsson. 2014. Role of Lactobacillus reuteri cell and mucus-binding protein $\mathrm{A}(\mathrm{CmbA})$ in adhesion to intestinal epithelial cells and mucus in vitro. Microbiology 160:671-681. https://doi.org/10.1099/mic.0.073551-0.

Kebouchi, M., W. Galia, M. Genay, C. Soligot, X. Lecomte, A. A. Awussi, C. Perrin, E. Roux, A. Dary-Mourot, and Y. Le Roux. 2016. Implication of sortase-dependent proteins of Streptococcus thermophilus in adhesion to human intestinal epithelial cell lines and bile salt tolerance. Appl. Microbiol. Biotechnol. 100:36673679. https://doi.org/10.1007/s00253-016-7322-1.

Kos, B., J. Susković, S. Vuković, M. Simpraga, J. Frece, and S. Matosić. 2003. Adhesion and aggregation ability of probiotic strain Lactobacillus acidophilus M92. J. Appl. Microbiol. 94:981-987. https://doi .org/10.1046/j.1365-2672.2003.01915.x.

Lee, J. E., J. Lee, J. H. Kim, Cho, Lee, Park, Koh, Kang, Kim, and Yoo.. 2019. Characterization of the anti-cancer activity of the probiotic bacterium Lactobacillus fermentum using 2D vs. 3D culture in colorectal cancer cells. Biomolecules 9:557. https://doi .org/10.3390/biom9100557.

Lee, K. W., J. Y. Park, H. D. Sa, J. H. Jeong, D. E. Jin, H. J. Heo, and J. H. Kim. 2014. Probiotic properties of Pediococcus strains isolated from jeotgals, salted and fermented Korean sea-food. Anaerobe 28:199-206. https://doi.org/10.1016/j.anaerobe.2014.06.013.

Lordan, R., A. Tsoupras, and I. Zabetakis. 2017. Phospholipids of animal and marine origin: Structure, function, and anti-inflam- 
matory properties. Molecules 22:1964. https://doi.org/10.3390/ molecules22111964.

MacKenzie, D. A., F. Jeffers, M. L. Parker, A. Vibert-Vallet, R. J. Bongaerts, S. Roos, J. Walter, and N. Juge. 2010. Strain-specific diversity of mucus-binding proteins in the adhesion and aggregation properties of Lactobacillus reuteri. Microbiology 156:33683378. https://doi.org/10.1099/mic.0.043265-0.

Martín-Platero, A. M., E. Valdivia, M. Maqueda, and M. MartínezBueno. 2009. Characterization and safety evaluation of enterococci isolated from Spanish goats' milk cheeses. Int. J. Food Microbiol. 132:24-32. https://doi.org/10.1016/j.ijfoodmicro.2009.03.010.

Miyoshi, Y., S. Okada, T. Uchimura, and E. Satoh. 2006. A mucus adhesion promoting protein, MapA, mediates the adhesion of Lactobacillus reuteri to Caco-2 human intestinal epithelial cells. Biosci. Biotechnol. Biochem. 70:1622-1628. https://doi.org/10.1271/bbb .50688 .

Morifuji, M., M. Kitade, C. Oba, T. Fukasawa, K. Kawahata, T. Yamaji, Y. Manabe, and T. Sugawara. 2017. Milk fermented by lactic acid bacteria enhances the absorption of dietary sphingomyelin in rats. Lipids 52:423-431. https://doi.org/10.1007/s11745-017-4247 -0 .

Naughton, J., G. Duggan, B. Bourke, and M. Clyne. 2014. Interaction of microbes with mucus and mucins. Gut Microbes 5:48-52. https: //doi.org/10.4161/gmic.26680.

Penna, A. L. B., A. T. Paula, S. N. Casarotti, V. Diamantino, and L. Silva. 2015. Overview of the functional lactic acid bacteria in the fermented milk products. Benef. Microbes Fermented Funct. Foods 1:100-154.

Ramiah, K., C. A. van Reenen, and L. M. T. Dicks. 2009. Expression of the mucus adhesion gene $M u b$, surface layer protein Slp and adhesion-like factor EF-TU of Lactobacillus acidophilus ATCC 4356 under digestive stress conditions, as monitored with real-time PCR. Probiotics Antimicrob. Proteins 1:91-95. https://doi.org/10 .1007/s12602-009-9009-8.

Ranadheera, R., S. K. Baines, and M. C. Adams. 2010. Importance of food in probiotic efficacy. Food Res. Int. 43:1-7. https://doi.org/ 10.1016/j.foodres.2009.09.009.

Reuter, G. 1985. Elective and selective media for lactic acid bacteria. Int. J. Food Microbiol. 2:55-68. https://doi.org/10.1016/0168 $-1605(85) 90057-1$.

Roos, S., and H. Jonsson. 2002. A high-molecular-mass cell-surface protein from Lactobacillus reuteri 1063 adheres to mucus components. Microbiology 148:433-442. https://doi.org/10.1099/ 00221287-148-2-433.

Ruiz, L., A. Margolles, and B. Sánchez. 2013. Bile resistance mechanisms in Lactobacillus and Bifidobacterium. Front. Microbiol. 4:396. https://doi.org/10.3389/fmicb.2013.00396.

Schillinger, U., and W. H. Holzapfel. 2003. Chapter 8: Culture media for lactic acid bacteria. In Handbook of Culture Media for Food Microbiology. J. E. L. Corry, G. D. W. Curtis, and R. M. Baird, ed. Elsevier, Amsterdam, the Netherlands.

Schubert, M., C. Contreras, N. Franz, and J. Hellhammer. 2011. Milkbased phospholipids increase morning cortisol availability and improve memory in chronically stressed men. Nutr. Res. 31:413-420. https://doi.org/10.1016/j.nutres.2011.05.012.

Singh, K., B. Kallali, A. Kumar, and V. Thaker. 2011. Probiotics: A review. Asian Pac. J. Trop. Biomed. 1:S287-S290. https://doi.org/ 10.1016/S2221-1691(11)60174-3.

Singh, T. P., R. K. Malik, and G. Kaur. 2016. Cell surface proteins play an important role in probiotic activities of Lactobacillus reuteri. Nutrire 41:5. https://doi.org/10.1186/s41110-016-0007-9.
Sirichokchatchawan, W., P. Pupa, P. Praechansri, N. Am-in, S. Tanasupawat, P. Sonthayanon, and N. Prapasarakul. 2018. Autochthonous lactic acid bacteria isolated from pig faeces in Thailand show probiotic properties and antibacterial activity against enteric pathogenic bacteria. Microb. Pathog. 119:208-215. https://doi .org/10.1016/j.micpath.2018.04.031.

Sleytr, U. B., B. Schuster, E.-M. Egelseer, and D. Pum. 2014. S-layers: Principles and applications. FEMS Microbiol. Rev. 38:823-864. https://doi.org/10.1111/1574-6976.12063.

Smit, E., F. Oling, R. Demel, B. Martinez, and P. H. Pouwels. 2001. The S-layer protein of Lactobacillus acidophilus ATCC 4356: Identification and characterisation of domains responsible for S-protein assembly and cell wall binding. J. Mol. Biol. 305:245-257. https:/ /doi.org/10.1006/jmbi.2000.4258.

Snow, D. R., R. E. Ward, A. Olsen, R. Jimenez-Flores, and K. J. Hintze. 2011. Membrane-rich milk fat diet provides protection against gastrointestinal leakiness in mice treated with lipopolysaccharide. J. Dairy Sci. 94:2201-2212. https://doi.org/10.3168/jds.2010-3886.

Spitsberg, V. L. 2005. Invited review: Bovine milk fat globule membrane as a potential nutraceutical. J. Dairy Sci. 88:2289-2294. https://doi.org/10.3168/jds.S0022-0302(05)72906-4.

Vesper, H., E.-M. Schmelz, M. N. Nikolova-Karakashian, D. L. Dillehay, D. V. Lynch, and A. H. Merrill Jr.. 1999. Sphingolipids in food and the emerging importance of sphingolipids to nutrition. J. Nutr. 129:1239-1250. https://doi.org/10.1093/jn/129.7.1239.

Vidhyasagar, V., and K. Jeevaratnam. 2013. Evaluation of Pediococcus pentosaceus strains isolated from Idly batter for probiotic properties in vitro. J. Funct. Foods 5:235-243. https://doi.org/10.1016/ j.jff.2012.10.012.

Walter, J., C. Hertel, G. W. Tannock, C. M. Lis, K. Munro, and W. P. Hammes. 2001. Detection of Lactobacillus, Pediococcus, Leuconostoc, and Weissella species in human feces by using group-specific PCR primers and denaturing gradient gel electrophoresis. Appl. Environ. Microbiol. 67:2578-2585. https://doi.org/10.1128/AEM .67.6.2578-2585.2001.

Wegkamp, A., B. Teusink, W. M. De Vos, and E. J. Smid. 2010. Development of a minimal growth medium for Lactobacillus plantarum. Lett. Appl. Microbiol. 50:57-64. https://doi.org/10.1111/j.1472 -765X.2009.02752.x.

Xu, H., H. S. Jeong, H. Y. Lee, and J. Ahn. 2009. Assessment of cell surface properties and adhesion potential of selected probiotic strains. Lett. Appl. Microbiol. 49:434-442. https://doi.org/10 .1111/j.1472-765X.2009.02684.x.

Zoumpopoulou, G., A. Tzouvanou, E. Mavrogonatou, V. Alexandraki, M. Georgalaki, R. Anastasiou, M. Papadelli, E. Manolopoulou, M. Kazou, D. Kletsas, K. Papadimitriou, and E. Tsakalidou. 2018. Probiotic features of lactic acid bacteria isolated from a diverse pool of traditional Greek dairy products regarding specific strainhost interactions. Probiotics Antimicrob. Proteins 10:313-322. https://doi.org/10.1007/s12602-017-9311-9.

\section{ORCIDS}

Erica Kosmerl ๑ https://orcid.org/0000-0002-0751-4990

Rafael Jiménez-Flores @ https://orcid.org/0000-0003-4905-5021

Israel García-Cano @ https://orcid.org/0000-0003-2891-7286 